\title{
Lung Deposition and Inspiratory Flow Rate in Patients with Chronic Obstructive Pulmonary Disease Using Different Inhalation Devices: A Systematic Literature Review and Expert Opinion [Corrigendum]
}

\author{
Baloira A, Abad A, Fuster A, et al. Int J Chron Obstruct \\ Pulmon Dis. 2021;16:1021-1033.
}

Page 1026, left column, fourth paragraph, the text "Inhaler devices are many times classified as low- $(30 \mathrm{~L} / \mathrm{min}$ or below), medium- $(\sim 30-60 \mathrm{~L} / \mathrm{min})$, and high- resistance
( $>60 \mathrm{~L} / \mathrm{min}$ ) devices" should read "Inhaler devices are many times classified as low- $(>60 \mathrm{~L} / \mathrm{min})$, medium$(\sim 30-60 \mathrm{~L} / \mathrm{min})$, and high-resistance $(30 \mathrm{~L} / \mathrm{min}$ or below) devices".

The authors apologize for this error.

\section{Publish your work in this journal}

The International Journal of COPD is an international, peer-reviewed journal of therapeutics and pharmacology focusing on concise rapid reporting of clinical studies and reviews in COPD. Special focus is given to the pathophysiological processes underlying the disease, intervention programs, patient focused education, and self managemen protocols. This journal is indexed on PubMed Central, MedLine and CAS. The manuscript management system is completely online and includes a very quick and fair peer-review system, which is all easy to use. Visit http://www.dovepress.com/testimonials.php to read real quotes from published authors. 